\title{
Parenting style and locus of control, motivation, and school adaptation among students with borderline intellectual functioning
}

\author{
Anna Maria Jankowska ${ }^{1 \cdot A, B, C, D, E, F}$, Anna Takagi ${ }^{2 \cdot D, E, F}$, Marta Bogdanowicz ${ }^{1 \cdot A, D, E}$, Jolanta Fonak ${ }^{3 \cdot D, E}$ \\ 1: Department of Developmental Psychology and Psychopathology, University of Gdansk, Gdansk, Poland \\ 2: McGill University, Montréal, Québec, Canada \\ 3: College of Education, Northeastern Illinois University, Chicago, USA
}

\section{BACKGROUND}

Parenting style impacts children's psychosocial development. Students with borderline intellectual functioning (BIF) are especially sensitive to the quality of parental care. The objective of this study was to compare parenting styles of mothers of children with BIF and mothers of typically developing peers, and establish associations between parenting styles and children's psychosocial traits, which determine their school functioning.

\section{PARTICIPANTS AND PROCEDURE}

Forty-two primary school students in Grades 4 to 6, their teachers, and mothers participated in the study. Based on their IQ level they comprised two groups: students with BIF (criterion group; $n=21$ ) and students with average IQ (comparison group; $n=21$ ). A series of measures were used to assess mothers' parenting style and students' psychosocial traits. Questionnaires measuring students' psychosocial properties were administered to children and their teachers in order to compare their perspectives.

\section{RESULTS}

Mothers of children with BIF in comparison to mothers in the control group presented greater inclinations towards over-parenting. Based on self-reports, students with BIF did not differ from their typically developing classmates in terms of school motivation, anxiety, locus of control, or social adjustment, despite their lower academic performance. According to teachers, students with BIF had significantly lower school motivation and delayed socialization. For students with BIF but not for the comparison group, a negative correlation was found between mothers' tendency to dominate over their child and students' locus of control and school motivation.

\section{CONCLUSIONS}

Children with BIF are especially sensitive to the quality of mothers' parenting style, which can have an adverse effect on their school adjustment.

\section{KEY WORDS}

borderline intellectual functioning; parenting styles; school motivation; locus of control; anxiety

CORRESPONDing AUthor - Anna Maria Jankowska, Ph.D., Department of Developmental Psychology

and Psychopathology, University of Gdansk, 4 Bażyńskiego Str., 80-952 Gdansk, Poland, tel. +48 5852344 03,

e-mail: amjankowska@hotmail.com

AUthors' CONtribution - A: Study design - B: Data collection - C: Statistical analysis - D: Data interpretation .

E: Manuscript preparation $\cdot F$ : Literature search $\cdot$ G: Funds collection

to Cite this ARTICLE - Jankowska, A. M., Takagi, A., \& Bogdanowicz, M. (2014). Parenting style and locus of control, motivation, and school adaptation among students with borderline intellectual functioning. Current Issues

in Personality Psychology, 2(4), 251-266.

RECEIVED 02.10.2014 · REVIEWED 20.10.2014 · ACCEPTED 18.11.2014 · PUBLISHED 19.12.2014 


\section{BACKGROUND}

The quality of the parent-child relationship is the foundation for every human's life and has great importance for all domains of development (McCollum, Gooler, Appl, \& Yates, 2001). Parental unconditional acceptance, respect, and democratic cooperation with the child are most beneficial (Gfroerer, Kern, \& Curlette, 2004; Ziemska, 1977) and are particularly vital for the course of the child's psychological and social growth. The first typology of parenting styles was proposed by Baumrind (1967), who differentiated three styles: permissive, authoritative, and authoritarian. Two dimensions further describe all three styles: responsiveness and demands. Authoritative parents are nurturing, compassionate, sensitive to the child's needs, and their expectations are appropriate for the child's age and abilities. Permissive parents are warm and friendly towards the child, although they most often have little or no control over their child's behaviour. In contrast, authoritarian parents are particularly demanding, restrictive, and punitive. Baumrind's ideas were adapted and further developed by Maccoby and Martin (1983) who proposed four categories of parenting styles: authoritative (demanding and responsive), authoritarian (demanding and unresponsive), permissive (responsive but not demanding), and neglectful (unresponsive and not demanding). At present, warmth, responsiveness, and quantity of control are considered the key factors that shape parenting styles (Coolahan, McWayne, \& Fantuzzo, 2002).

An authoritative parenting style is considered to be particularly developmentally appropriate, as it supports the child's autonomy and the development of positive self-esteem (Milevsky, Schlechter, Netter, \& Keehn, 2006; Reitman, Rhode, Hupp, \& Altobello, 2002; Russell, Crockett, \& Chao, 2010). Parenting styles also contribute to the process of school adaptation and for the duration of education (Gadeyne, Ghesquiere, \& Onghena, 2004). Students who perceive their parents as having an authoritative parenting style present a high level of academic performance (Cohen \& Rice, 1997). In adolescence, an authoritative parenting style is associated not only with the positive outcomes of academic education (Lamborn, Mounts, Steinberg, \& Dornbusch, 1991), but also with a greater degree of optimism (Baldwin, McIntyre, \& Hardaway, 2007), feelings of competence (Strage \& Brandt, 1999), and stronger motivation to learn (Gonzalez \& Wolters, 2006). In contrast, children raised by authoritarian parents present significantly lower self-esteem, feelings of incompetence, and tend to use less effective coping strategies (Kaisa, Hakan, \& Jari-erik, 2000; Smith \& Moore, 2012). Therefore, an authoritarian style impacts negatively on the child's academic performance (Pong, Johnston, \& Chen, 2010). Furthermore, excessive parental control, lack of trust, and strict discipline increase the risk of emotional and behavioural disorders among adolescents (Smith, Calkins, Keane, Anastopoulos, \& Shelton, 2004).

Children's motivation for learning depends on environmental factors including parental attitudes and expectations (Swanson, Valiente, \& Lemery-Chalfant, 2012). Academic motivation results from the child's need for achievement and selection of educational goals (Wigfield \& Cambria, 2010), which are frequently shaped within the family environment. Research confirms that children raised in families who support their autonomy develop internal motivation, whereas external motivation is most frequently observed among students whose parents exhibit a high level of control and discipline (Deci, Eghrari, Patrick, \& Leone, 1994). Furthermore, internal motivation to learn facilitates engagement with school tasks (Ali, Akhter, Shahzad, Sultana, \& Ramzan, 2011) and is associated with high academic achievement and effective adaptation to school educational requirements (Grouzet, Vallerand, Thill, \& Provencher, 2004; Mega, Ronconi, \& DeBeni, 2013; Vansteenkiste, Simons, Lens, Sheldon, \& Deci, 2004).

School motivation and anxiety are factors that strongly influence students' learning outcomes (Phillips, Pitcher, Worsham, \& Miller, 1980). Internal motivation and feelings of anxiety have been found to be negatively related (Gottfried, 1982). Furthermore, anxiety in high school reduces focus on educational tasks and results in the use of less effective problem-solving strategies. This, in turn, correlates with poor academic performance (Dusek, 1980). In addition, controlling parental behaviour is associated with high anxiety and the risk of depression (McLeod, Wood, \& Weisz, 2007).

The literature also supports the notion that parenting styles are related to the development of the child's locus of control (Meesters \& Muris, 2004). An internal locus of control is associated with the amount of parental warmth, care, and emotional intimacy (Dew \& Huebner, 1994; Suchman, Roundsaville, DeCoste, \& Luthar, 2007), as well as parental efforts to support the child's autonomy (Chorpita \& Barlow, 1998). In contrast, controlling and rejecting parenting is related to a child's external locus of control (Cohen, Sade, Benarroch, Pollak, \& GrossTsur, 2008a), which is primarily determined by the level of parental acceptance perceived by the child (Cohen, Biran, Aran, \& Gross-Tsur, 2008b). Over the past several decades, results of numerous studies have demonstrated relationships between students' external locus of control and school maladaptation, poor academic performance (Kee, 2005; Nesselroade, Musher-Eizenman, \& Schmitz, 2002), and increased risk of anxiety disorders and depression (Chorpita \& Barlow, 1998; Ostrander \& Herman, 2006). 
Not only are parenting styles of major significance for the achievement of academic success, but they are also linked with students' social adaptation. An authoritarian parenting style is associated with inadequate and poor social problem-solving strategies of a child (Jones, Rickel, \& Smith, 1980), withdrawal from peer relationships, frequent hostile response during emotional distress (Baumrind, 1971), and tendencies towards acting out (Forehand \& Nousiainen, 1993). According to Lamborn et al. (1991), children of authoritarian parents exhibit poor self-concept, inappropriate behaviour in a school setting, and a low level of engagement in educational activities. School maladaptation is especially prominent among students whose parents are emotionally distant, indifferent, and rigid (Kauffman et al., 2000; Maccoby \& Martin, 1983; Shumow, Vandell, \& Posner, 1998).

Borderline intellectual functioning (BIF) is the level of intellectual ability between the average range and mild mental retardation, which is within 1.01 to 2.00 standard deviations (APA, 2013). Descriptions of BIF in international diagnostic classifications are rather ambiguous (Ninivaggi, 2005) due to the heterogeneity of problems experienced by this population (Salvador-Carulla et al., 2013). The International Classification of Diseases (ICD-10) refers to BIF as an entity comprising of problems in cognitive functioning and awareness, whereas in the DSM-5 it is coded under developmental disorder (V92.89) requiring clinical help but is not an intellectual disorder (APA, 2013; WHO, 1994). The prevalence of individuals with BIF is approximately $13.60 \%$ of the general population. However, the actual number is frequently inaccurate and underrepresented (Gottlieb, Alter, Gottlieb, \& Wishner, 1994), as their overall representation may be significantly greater (Salvador-Carulla et al., 2013).

Youth with borderline intelligence experience a range of difficulties in educational, social, and health domains (Salvador-Carulla et al., 2013). Low intellectual abilities result in reduced ability to accomplish educational standards and, consequently, in poor academic achievement, grade retention, and even school dropout (Kaznowski, 2004; MacMillan, Gresham, Bocian, \& Lambros, 1998). Therefore, emotional distress, conduct problems, and mental disorders occur frequently in this population (Emerson, 2003; Dekker \& Koot, 2003; Hassiotis et al., 2008). The cycle of school failure starts at the beginning of their formal education when, due to lack of school readiness and delayed cognitive abilities, children with BIF are not able to perform as effectively as their classmates (Bocsa, 2003; Jankowska, Bogdanowicz, \& Takagi, 2014; Karende, Kanchan, \& Kulkarni, 2008). Chronic academic failure consequently leads to feelings of helplessness among students and decreases their motivation to invest any effort into academic tasks (Ames, 1992; Marsh \& Yeung, 1997; Wentzel,
1998), and these difficulties are particularly evident in students with intellectual disability (Bimler \& Kirkland, 2001). Students with BIF exhibit passive and indifferent attitudes towards school and academic activities (Bocsa, 2003). Experiences with frequent failure, despite their best efforts, lead to negative beliefs about their competence and ability to control their educational situation (Masi, Marcheschi, \& Pfanner, 1998; Ninivaggi, 2008). Students with severe learning difficulties tend to believe that both school failure and success are produced solely by external factors that are beyond their control and therefore impossible to change (Jacobsen, Lowery, \& DuCette, 1986). Unfortunately, this attitude only leads to further withdrawal from classroom participation and induces frustration. For borderline intelligence students, who tend to function in the periphery of the classroom, all these aforementioned factors increase the risk of school maladaptation (Ninivaggi, 2008).

Comparatively little is known about the quality of the parent-child relationship in families with children with BIF. The family environment and parenting styles may negatively influence the child's school and psychosocial functioning (Bocsa, 2003; Valliant \& Davis, 2000). It is believed that parents of children with intellectual disabilities may present more negative attitudes towards their children's difficulties. Mothers of children with ID exhibit characteristics of rejection, hostility, domination, permissiveness, or over-protection towards their children (Saravanan, 2012). Consequently, mothers of children with BIF present less engaged and unresponsive attitudes and perceive them to exhibit more behavioural issues, despite the lack of objective differences compared to typically developing peers (Fenning, Baker, Baker, \& Crnic, 2007). Moreover, when conduct difficulties were present in BIF children they were associated with mothers', but not fathers', adverse and controlling behaviours towards the child (Fenning et al., 2014). A negative family environment, of which children with BIF are at greater risk, increase the risk of emotional and conduct disorders, anxiety, and even depression (Emerson, 2003; Emerson \& Hatton, 2007).

Thus, the purpose of this study was to investigate the relationship between parenting styles, school motivation and anxiety, locus of control, and risk of maladaptation among students with BIF and their typically developing peers.

\section{PARTICIPANTS AND PROCEDURE}

\section{PARTICIPANTS}

Participants were 42 students in Grades 4 to 6 divided into two groups based on their results on the Raven's Progressive Matrices (RPM). The treatment 
group consisted of 21 students (12 females, 9 males, $M=11.90$ years) and were identified as having scores in borderline range (between 1.01 to 2.00 standard deviations below the mean) on the RPM. They also received a psychological-pedagogical assessment that confirmed below average intellectual abilities with no other co-occurring disorders or developmental disability. The comparison group consisted of 21 students ( 12 females, $M=11.70$ years) who scored within the average range on the RPM and had no diagnosis of developmental or learning disability. Participants were matched on classroom placement, age, and sex across the groups. Students' teachers and mothers participated in structured interviews and also completed surveys.

\section{PROCEDURE}

The study was conducted in a public primary school in Gdansk (Poland). Parental consent was obtained for 119 students (59 males) in Grades 4 to 6. All students were administered the RPM in a group setting. Based on their performance, students were identified as having borderline (i.e., below average) intellectual functioning $(n=21)$ or average intelligence $(n=21)$. Demographic information for each student was collected through structured interviews with teachers and parents. This information included: family environment, family income, parental age and educational level, history of pregnancy and delivery, the child's psychomotor development, and their current health status.

\section{MEASURES}

Parenting styles were measured using the Parenting Style Inventory of Ziemska (1981). The survey consists of 40 statements that parents rated on a 4-point Likert-type scale ranging from 'I strongly agree' to 'I strongly disagree.' The inventory is comprised of four scales that capture Authoritarian, Permissive, Overparenting, and Neglectful attitudes. Ziemska's typology of parenting styles can be described along two dimensions: dominance-submission and emotional distance-closeness. Dominant (or authoritarian) parents are strict and demanding and they expect obedience, allow very little dialogue with the child, set high expectations, and ignore the child's needs. Parents described by Ziemska as helpless (or permissive) have little control over their child's behavior and are submissive and incapable of setting boundaries or expectations. Distant (or neglectful) parents avoid being involved in their child's life, are unresponsive to their child's emotional needs, and provide very little support. Parents with high emotional concentration (or overparenting) on their child are extremely focused on the child's life and highly sensitive to his or her needs. They present a strong desire to protect them and tend to be over-reactive.

Students' school motivation and level of school anxiety were assessed using the 'My School and I' inventory (Zwierzyńska \& Matuszewski, 2006a). This survey consists of 73 self-descriptive statements that concern different school situations, to which students respond "yes", "no", or "?".

The Locus of Control Research Inventory (LCRI; Krasowicz \& Kurzyp-Wojnarska, 1990) was used to measure students' locus of control in school settings. This survey consists of 46 questions that comprise the Scale of Success (e.g., positive school events), Scale of Failures (e.g., negative school events), and the General Scale. High scores indicate an internal locus of control while low scores indicate an external locus of control.

Student's self-esteem was assessed using the Rosenberg Self-Esteem Scale (Rosenberg, 1965). This scale consists of 10 statements regarding general feelings about onself that students rated on a 4-point scale (from "Strongly agree" to "Strongly disagree").

To measure school adaptation, questionnaires were completed by both students and their teachers. Students completed the "My Classroom and I" (Zwierzyńska \& Matuszewski, 2006b) inventory, a selfreport measure consisting of 50 items that depict different social situations that occur in the classroom. Five variables are used to describe the level of school adaptation of a student: feeling insignificant (e.g., feeling ignored by peers), feeling threatened (e.g., socially anxious), feeling unappreciated (e.g., having poor social skills), isolation (e.g., feeling isolated, actively rejected by peers), egocentrism (e.g., being egocentric, inconsiderate, not helpful towards peers), and aggression (e.g., behaving aggressively towards others). Teachers' assessments of students' school adaptation were measured using the Children's Behaviour Inventory by Markowska and Szafraniec (1980). Teachers rated students on 50 items comprising five scales: $\mathrm{mo}^{-}$ tivation for learning, antisocial behaviours, behavioural inhibition, socialization, and sexual behaviours (which was not considered in the present study). All measures have been identified as having strong validity and reliability.

Students' average grades across subjects were used as a measure of their academic performance.

In order to ensure students' ability to comprehend and complete the questionnaires, they were asked to explain the meaning of randomly chosen items from the surveys. Children in both groups demonstrated good understanding of the examined items.

Data were analyzed using student's $t$-tests for independent groups, Pearson correlations, and $\chi^{2}$ tests using SPSS software. 


\section{RESULTS}

\section{PARENTING STYLES}

Mothers of students in both groups did not differ regarding authoritarian, permissive, and neglectful parenting styles. However, significant differences were observed on the overparenting subscale $(t(28)=2.29$, $p=.030)$. Specifically, mothers of students with BIF had higher emotional concentration on the child and their problems. In addition, for these students, emotional concentration of their mothers was negatively correlated with feeling insignificant $(r=-.54$, $p=.019)$ and isolation $(r=-.48, p=.042)$ on the 'My Classroom and I' inventory. Such correlations were not found in the comparison group. Thus, for children with borderline intelligence, the results suggest that a higher level of parental concentration is associated with a greater degree to which the children felt accepted and included by their peers. Moreover, these students' gregariousness and openness to contact with their peers was higher.

For children with borderline intelligence, mothers' authoritarian style was negatively correlated with students' school motivation $(r=-.48, p=.045)$ and locus of control regarding academic success ( $r=-.48, p=.046$ ). Significant correlations were not found in the comparison group. However, in general for both groups, school motivation was positively correlated with the Scale of Success on the LCRI ( $r=.44, p=.049$ for the treatment group; $r=.44$, $p=.045$ for the comparison group).

There were no significant group differences on self-report measures of school motivation, school anxiety, locus of control, self-esteem, or level of school adaptation. However, there were significant correlations among these variables for students having borderline intelligence and these are discussed below.

\section{MOTIVATION FOR ACADEMIC LEARNING}

While self-reported motivation for academic learning was lower in students having borderline intelligence than in students with average intelligence, this difference was not statistically significant $(t(40)=1.68, p=.101)$. However, there was a significant difference in teacher reported motivation for learning in that students having borderline intelligence were perceived to be less motivated to undertake learning than students with average intelligence $(t(40)=3.15, p=.003)$. In addition, students having borderline intelligence had significantly lower academic grades than children with average intelligence $(t(40)=3.33, p=.002)$.

Furthermore, for students in the borderline intelligence group, school performance (grades) was sig- nificantly correlated with self-reported motivation for learning $(r=.63, p<.001)$, teacher reported motivation for learning $(r=.72, p<.001)$, the behavioral inhibition $(r=-.49, p=.023)$ and socialization $(r=.47, p=.023)$ subscales of the "Children's Behaviour Inventory". In the comparison group, school performance was significantly correlated with self-reported motivation for learning and behavioral inhibition.

\section{SCHOOL ANXIETY}

In terms of school anxiety, there were no significant differences across groups $(t(40)=1.07, p=.291)$ and both groups reported an average level of anxiety. However, in students with below average intelligence, school anxiety was positively correlated with locus of control for school success $(r=.52, p=.016)$. A similar correlation was not observed in the control group. Thus, for students having borderline intelligence, a lower level of school anxiety may be accompanied by a more externalized feeling of control over educational success.

Further analysis of responses on the "My School and I" inventory indicated significant correlations between school anxiety and feelings threatend $(r=.74, p<.001)$ in students having borderline intelligence. For both groups of students, school anxiety was significantly correlated with behavioral inhibition $(r=.49, p=.030)$.

\section{LOCUS OF CONTROL}

While students with borderline intelligence had lower scores on each of the three scales of the "Locus of Control Research Inventory" (Success, Failure and General Scale), the difference was not statistically significant. Thus, children with different levels of intellectual functioning did not differ in terms of locus of control over positive events (Scale of Success), negative events (Scale of Failures), or a general measure of locus of control (Full Scale).

\section{SOCIAL ADAPTATION}

There were no group differences in self-reported school adaptation as measured by the "My Classroom and I" inventory. Both groups reported an average level of interest by their peers (feeling insignificant), feeling safe in their peer group (feel threatened), feeling appreciated and accepted by peers (isolation), acting for the benefit for others (egocentrism), and aggression.

However, according to teacher reports, students with BIF exhibit a significantly lower level of school motivation $(t(40)=3.15, p=.003)$ and socialization 
Table 1

Means, standards deviations, and mean differences

\begin{tabular}{|c|c|c|c|c|c|c|c|}
\hline \multirow[t]{2}{*}{ Variables } & \multicolumn{2}{|c|}{ BIF } & \multicolumn{2}{|c|}{ Average IQ } & \multirow[b]{2}{*}{$t$} & \multirow[b]{2}{*}{$d f$} & \multirow[b]{2}{*}{ Sig. (2-tailed) } \\
\hline & $M$ & $S D$ & M & $S D$ & & & \\
\hline Authoritarian & 11.78 & 4.02 & 10.33 & 2.90 & 1.07 & 28 & .294 \\
\hline Permissive & 11.67 & 3.36 & 10.75 & 2.56 & 0.80 & 28 & .430 \\
\hline Neglectful & 6.72 & 3.56 & 4.92 & 2.02 & 1.77 & 28 & .088 \\
\hline Overparenting & 13.22 & 3.99 & 10.00 & 3.44 & 2.28 & 28 & $.030^{*}$ \\
\hline School Motivation & 27.86 & 10.90 & 33.95 & 12.56 & 1.68 & 40 & .101 \\
\hline LOC General Scale & 24.62 & 3.72 & 26.19 & 5.10 & 1.14 & 40 & .261 \\
\hline LOC Success & 11.48 & 2.62 & 12.86 & 3.14 & 1.55 & 40 & .129 \\
\hline LOC Faulire & 13.14 & 2.20 & 13.33 & 2.94 & 0.24 & 40 & .813 \\
\hline School Anxiety & 34.81 & 16.17 & 29.62 & 15.23 & 1.07 & 40 & .291 \\
\hline Self-esteem & 26.62 & 4.86 & 27.90 & 4.61 & -0.88 & 40 & .385 \\
\hline Academic Performance & 3.60 & 0.71 & 4.30 & 0.67 & -3.33 & 40 & $.002^{* *}$ \\
\hline Feeling Insignificant & 34.86 & 9.26 & 40.14 & 6.40 & 1.10 & 33 & .072 \\
\hline Feeling Threatened & 13.90 & 7.99 & 14.79 & 7.21 & 0.34 & 33 & .742 \\
\hline Feeling Unappreciated & 18.33 & 4.97 & 20.07 & 5.24 & 0.98 & 33 & .329 \\
\hline Isolation & 30.52 & 7.14 & 34.07 & 7.07 & 1.45 & 33 & .158 \\
\hline Egocentrism & 42.76 & 9.14 & 46.79 & 4.87 & 1.69 & 33 & .101 \\
\hline Aggression & 15.67 & 19.01 & 10.93 & 3.67 & 1.11 & 33 & .366 \\
\hline School Motivation (teacher) & 32.86 & 9.11 & 42.14 & 9.96 & -3.15 & 40 & $.003^{* *}$ \\
\hline Antisocial Behavior (teacher) & 26.76 & 7.97 & 25.24 & 8.03 & 0.62 & 40 & .541 \\
\hline Behavioral Inhibition (teacher) & 33.67 & 7.07 & 28.14 & 7.05 & 2.54 & 40 & .015 \\
\hline Socialization (teacher) & 36.10 & 7.64 & 42.81 & 5.30 & -3.31 & 40 & $.002^{* *}$ \\
\hline
\end{tabular}

Note. ${ }^{*} p<0.05 ;{ }^{* *} p<.01 ;{ }^{* * *} p<.001$

$(t(40)=-3.31, p=.002)$ and significantly greater difficulties with inhibition $(t(40)=2.54, p=.015)$.

\section{SELF-ESTEEM}

No differences in the level of self-esteem were observed across the groups $(t(40)=.88, p=.385)$. However, for students having borderline intelligence (but not in the comparison group), self-esteem was significantly correlated with the school adaptation subscales feeling threatened ( $r=-.44, p=.045)$, behavioral inhibition $(r=-.49, p=.024)$ and socialization $(r=.46$, $p=.037)$.

\section{FAMILY FACTORS}

Regarding family factors, students having borderline intelligence were significantly more frequent- ly brought up in incomplete families $\left(\chi^{2}(1)=4.63\right.$, $p=.031)$, having a low family income $\left(\chi^{2}(2)=6.35\right.$, $p=.042)$, and living in very modest residential conditions $\left(\chi^{2}(2)=5.54, p=.063\right)$. In addition, level of education was significantly different for mothers across groups $\left(\chi^{2}(2)=8.66, p=.013\right)$. Fourteen percent of mothers of children with borderline intelligence had a higher education, while $52 \%$ of mothers of children in the comparison group had higher education. No differences in fathers' level of education were observed $\left(\chi^{2}(2)=4.21, p=.122\right)$. However, $62 \%$ of fathers of children with borderline intelligence received exclusively vocational education, while that percentage was $20 \%$ in the comparison group (Tables 1-3).

\section{DISCUSSION}

Students identified as having borderline intelligence did not differ from peers with average mental abili- 
Anna Maria Jankowska, Anna Takagi, Marta Bogdanowicz, Jolanta Jonak

Table 2

Correlations with parenting style among mothers of student with borderline intellectual functioning

\begin{tabular}{ccccc}
\hline Variables & Authoritarian & Permissive & Overparenting & Neglectful \\
\hline School Motivation (student) & $-.48^{*}$ & .39 & -.25 & -.29 \\
LOC General Scale & -.33 & -.18 & -.20 & -.18 \\
LOC Success & $-.48^{*}$ & -.09 & -.02 & .02 \\
LOC Failure & .04 & -.20 & -.33 & -.34 \\
School Anxiety & -.31 & .08 & .18 & .04 \\
Self-esteem & .33 & .18 & .42 & .18 \\
Academic Performance & -.27 & .29 & -.34 & -.18 \\
Feeling Insignificant & .08 & .38 & $-.54^{*}$ & -.21 \\
Feeling Threatened & -.36 & -.02 & .22 & -.03 \\
Feeling Unappreciated & .03 & .30 & -.17 & -.15 \\
Isolation & .06 & .18 & $-.48^{*}$ & -.07 \\
Egocentrism & -.33 & .28 & -.45 & -.16 \\
Aggression & .02 & .32 & -.22 & -.05 \\
Behavioral Inhibition (teacher) & -.13 & .10 & -.11 & .24 \\
Socialization (teacher) & -.27 & .19 & -.28 & $-.53^{*}$
\end{tabular}

Note. ${ }^{*} p<.05$

ties in terms of their self-reported level of motivation for conducting various academic activities, experiences of school anxiety, self-esteem, locus of control, or level of school adaptation. However, their level of academic achievement was significantly lower. These results are not entirely consistent with previous studies that have found that students suffering from learning difficulties and academic failures exhibit decreased motivation for learning (Levine, 2003), higher level of anxiety (Artigas-Pallarés, Rigau-Ratera, \& García-Nonell, 2007), decreased level of self-esteem (Sangeeta \& Krishna, 2009), and belief that the factors determining academic success are beyond their control (Kee, 2005; Nesselroade et al., 2002). However, the results are consistent with research conducted by Chovan and Morrison (1984) who observed that students suffering from learning difficulties do not always differ from their peers in terms of a higher level of anxiety or a lower level of self-esteem.

The absence of observed differences between the groups may be related to a lack of academic failures experienced by the children in this study, thus far, as they were relatively young (i.e., in Grades 4 to 6). That is, school anxiety has previously been found to increase together with the number of years spent in the educational system (Zwierzyńska \& Matuszewski, 2006b). Another significant factor may be that all the students with BIF were provided support and services by a school psychologist. Furthermore, teachers in Poland are obligated to adjust educational requirements and progress evaluation methods according to these children's psycho-physical abilities. That factor may make learning in school less frustrating for these students and protect against feelings of failure despite their lower achievement relative to their peers. Students are given the ability to experience satisfaction by being involved in school activities, which exerts a secondary influence on the level of motivation and feelings of autonomy and control, which in turn reduces the risk of anxiety.

The results of this study are consistent with those of Pintrich, Anderman, and Klobucar (1994), who found that students with learning difficulties did not differ from typically-developing peers in terms of their level of internal motivation, school anxiety, or self-efficacy. Their research also demonstrated that those students did not exhibit a higher level of learned helplessness than their peers, despite their tendency to attribute academic successes and failures to external factors. However, students with learning difficulties have a significantly lower level of meta-cognitive abilities. The absence of differences between the groups in this study on the above-mentioned variables may be related to a decreased level 
Table 3

Correlations with parenting style among mothers of students with average IQ

\begin{tabular}{|c|c|c|c|c|}
\hline Variables & Authoritarian & Permissive & Overparenting & Neglectful \\
\hline School Motivation (student) & .41 & -.02 & .04 & -.24 \\
\hline LOC General Scale & .42 & .41 & .28 & -.00 \\
\hline LOC Success & .30 & .38 & .28 & -.06 \\
\hline LOC Failure & .44 & .33 & .19 & .08 \\
\hline School Anxiety & -.39 & -.03 & -.31 & -.50 \\
\hline Self-esteem & .54 & -.24 & .31 & .36 \\
\hline Academic Performance & -.08 & -.47 & .08 & .06 \\
\hline Feeling Insignificant & -.00 & $-.65^{*}$ & -.49 & -.44 \\
\hline Feeling Threatened & .21 & .52 & -.07 & -.14 \\
\hline Feeling Unappreciated & -.39 & $-.68^{*}$ & -.53 & -.50 \\
\hline Isolation & -.31 & $-.67^{*}$ & -.33 & -.35 \\
\hline Egocentrism & -.04 & $-.74^{* *}$ & -.28 & -.13 \\
\hline Aggression & -.45 & .47 & -.13 & .15 \\
\hline School Motivation (teacher) & -.22 & $-.60^{*}$ & -.08 & -.24 \\
\hline Antisocial Behavior (teacher) & .37 & .39 & .32 & .10 \\
\hline Behavioral Inhibition (teacher) & -.43 & .18 & -.27 & -.54 \\
\hline Socialization (teacher) & -.48 & -.28 & -.28 & -.53 \\
\hline
\end{tabular}

Note. ${ }^{*} p<.05$

of self-awareness in students having borderline intelligence. As reported by Boekaerts (1999), self-awareness is a significant component of meta-cognition and the ability to engage in self-regulated learning. While the measures used in this study were largely based on self-report, students having borderline intelligence have been found to exhibit poor self-awareness (Bebko \& Luhaorg, 1998). Thus, it is possible that a restricted ability to self-reflect had an influence on the results obtained in the present study. Furthermore, previous research has found that children who perceive their parents to be authoritarian exhibit a weaker self-concept (Lamborn et al., 1991). It is also important to note that the small sample size of each group in this study may have precluded any evidence of group differences.

Thus, a discrepancy between students' and teachers' perspectives on school motivation and level of adaptation may be related to low self-awareness in students having borderline intelligence. According to self-reports, these students did not differ from students with average intelligence in their school engagement and ability to complete assignments, or in their level of social adaptation and functioning in their peer groups. However, differences were found across groups based on teacher reports. That is, teachers perceived children with BIF as less mo- tivated for academic learning and exhibited greater difficulties in adaptation than students with average intelligence. These results, as identified by teachers' responses on the "Children's' Behaviour Inventory", are consistent with research by Bimler and Kirkland (2001). These authors found that $95 \%$ of teachers considered students with BIF to have a low level of motivation for academic learning. Thus, due to weak academic performance and difficulties during lessons (e.g., working at a slower pace, becoming confused, and failing to keep up with the rest of the class), students having borderline intellectual functioning may be considered to be unmotivated and lazy by their teachers. These students experience additional difficulties in the classroom and may appear to be less engaged. As demonstrated by Artigas-Pallarés et al. (2007), students having borderline intelligence were reported to have significant difficulties maintaining attention, had minimal engagement, lack of independence, and were overly dependent on adults. Furthermore, difficulties in the classroom and with following lessons were associated with limited ability to work independently, understand instructions (particularly when given verbally), and slow speed of thinking and acquisition of material (Shaw, 2008). Thus, in observing students with BIF in the classroom, one might hastily conclude that their motivation is low. Teach- 
ers' beliefs about their students' motivation are significant for the process of education. They may secondarily influence the level of student engagement in learning as, in an indirect manner, they determine the instructional strategies used by the teacher as well as the teacher's level of effort and investment in teaching (Wenglinski, 2000).

Using teachers' responses on the "Children's Behaviour Inventory", low motivation for learning, low socialization, and high inhibition have been found to contribute significantly to social maladjustment (Markowska \& Szafraniec, 1980). In the present study, students having borderline intelligence were reported to exhibit lower aspirations for learning as well as apathy, withdrawal, a passive attitude and low classroom engagement, and low motivation to establish and maintain warm relationships with peers. In addition, high inhibition and poor socialization in students having below average intelligence are consistent with results by Dyduch (1999). One of the fundamental criteria of interpersonal attractiveness, in the early primary school grades in particular, are learning and achievement outcomes. The poorer the achievement of a child, the more likely it is that that child will be less popular in their peer group (Tyszkowa, 1990). In the present study, academic performance (as assessed by average grade) significantly correlated with academic motivation, behavioral inhibition, and socialization as reported by the teacher. Among students experiencing long-term academic failures, particularly with those having lower cognitive abilities, two extreme types of behaviour are frequently observed: apathy and hyperactivity (Wyczesany, 2004). For these students, inhibition is apparent in both the cognitive and emotional domains (Masi et al., 1998). Inhibition may result from internal conflicts in that individuals with BIF exhibit insufficient coping in emotionally stressful situations and, as a consequence, a low level of inhibition in response to internal conflicts. Inhibited children frequently do not present major difficulties in terms of their behaviour (which may contribute to the absence of differences in assessments of their conduct), are quiet, withdrawn, and invisible. Such an attitude results most frequently from a lack of confidence in their own abilities and from feelings of inferiority. They may constitute a defense mechanism and allow the child to go unnoticed in the classroom and avoid the risk of exposing their difficulties or limited abilities (Dembo, 1997).

A low level of socialization in students having borderline intelligence was also confirmed by results of longitudinal research conducted by Bosca (2003). Based on her observations, from the beginning of their education these students were less popular and socially attractive than students with higher intelligence. They were selected less frequently to be partners for games or for friendship and they established fewer positive relationships with their peers. According to Cooter and Cooter (2004), these students' lack of social adaptation results from their lower cognitive abilities, limited ability to cope with stressful and difficult situations, and decreased ability to control impulses.

In the present study, relationships between motivation for learning, locus of control regarding educational success, and school anxiety were observed in students with below average intelligence. In students with average intelligence, academic motivation and locus of control for academic success were significantly related. These results are consistent with previous research demonstrating the relationship between motivation, academic performance, and locus of control (Kalechstein \& Nowicki, 1997; Kee, 2005; Nesselroade et al., 2002). Low motivation for learning is accompanied by an externally-located feeling of control. Students experiencing long-term academic failures exhibit a tendency to perceive academic success as being influenced by external factors, which remain beyond their control and over which they have no influence themselves (Jacobsen et al., 1986). In the present study, for students who were identified as having borderline intelligence, a significant relationship between anxiety and locus of control in the context of academic success was observed. The less control over positive educational events these students experienced (i.e., the more external locus of control they expressed), the less school anxiety they reported. These results are not entirely consistent with previous research in that a higher level of anxiety has been found in students exhibiting an external locus of control (Dilmaç, Hamarta, \& Arslan, 2009; Nunn \& Parish, 1992). Thus, the relationship between locus of control and anxiety found in this study may be a function of a defense mechanism used by children with learning difficulties. More specifically, students who do not feel responsible for positive outcomes in their learning believe that they are beyond their control. This belief then protects them against experiencing additional disappointment and negative emotions that may arise from experiencing academic failures. Students who experience learning failures tend to explain the causes of academic success in terms of external factors (i.e., those beyond their control) such as good luck (Jacobsen et al., 1986; Pintrich et al., 1994). That strategy may in turn protect against negative and difficult thoughts concerning their own intellectual competencies. Spionek (1973) pointed out that students whose parents have excessively high expectations and ambitions experience strong feelings of guilt in connection with learning failures. These children often exhibit a tendency to assume responsibility if positive learning outcomes are not achieved.

For students having borderline intelligence, a pattern of significant correlations was observed between 
particular variables. Aside from those observed among dominating attitudes of parents, motivation for learning, and locus of control for educational success, a clear network of correlations was evident. As demonstrated by previous research, a higher level of anxiety is accompanied by more intense shyness, inhibition, and feelings of threat or danger related to the peer group (Gindrych, 2002; Masi et al., 1998). Individuals who are inhibited also exhibit apathy, low levels of activity, psychomotor retardation, withdrawal from social engagement in the classroom, and a low level of motivation to participate in group activities (Wyczesany, 2004). Furthermore, these individuals may exhibit dysphoria, anxiety, or shyness. The higher the level of inhibition, the greater the extent to which a child is observed to suffer from difficulties in establishing and maintaining positive peer relationships, passivity, and withdrawal from social contacts (Markowska \& Szafraniec, 1980). As a rule, children are afraid of being laughed at, teased, accosted, or rejected by their peers (Obuchowska, 1981). For those reasons, students who are convinced that they lack their own value and competence (a low self-esteem) are especially motivated to avoid situations in which they would be in danger of confronting criticism by the teacher or negative reactions of peers (Dembo, 1997). A sense of danger in the peer group and inhibition are related to the student's self-esteem which, in turn, is related to their level of socialization. Individuals with borderline intelligence experience difficulties in establishing and maintaining positive interpersonal relationships and have few sources of social support, which exert a secondary influence on their degree of socialization (Hassiotis et al., 2008). As noted earlier, a low level of socialization in students with below average intelligence has also been confirmed by Bosca (2003).

Mothers of students having borderline intelligence exhibit a significantly stronger tendency towards excessive emotional concentration on the child than mothers of children with average intelligence. Those observations may be interpreted as resulting from increased anxiety of the parent of a child who experiences developmental difficulties. As has been previously shown, the parent-child relationship involving a child with developmental difficulties is not symmetrical. That is, parents be may be more intrusive, have a tendency towards 'managing' the child, or take over control (Costigan, Floyd, Harter, \& McClintock, 1997; Floyd, Harter, \& Costigan, 2004).

In terms of the other parental attitudes, the groups in this study did not differ. However, differences did occur in terms of the relationships between parental attitudes and other variables. For children with borderline intelligence, there was an inverse relationship between an authoritarian parenting style and the child's motivation for learning and locus of control for academic success. Although the correla- tion between strict, dominating, and demanding parenting style and children's level of motivation was not high, the results suggest that a more rigid and demanding attitude of mothers will be accompanied by a lower level of motivation in children having borderline intelligence. Spionek (1973) pointed out that setting excessively high standards for children with below average intelligence causes strong discomfort associated with feeling unable to satisfy the aspirations of their parents. These children experience sharp disappointment and feelings of guilt associated with the knowledge that they have lower cognitive abilities and this, in turn, leads to a gradual decrease in their level of motivation for learning and need for achievement. Research has also indicated that parents are more likely to interpret children's academic performance as resulting from their skills and efforts they make in learning rather than considering the level of task difficulty or the competences of the teacher (Kinlaw, Kurtz-Costes, \& Goldman-Fraser, 2001; Stevenson, Chen, \& Uttal, 1990). In addition, parents attribute success to characteristics of the child such as their skills (Rytkönen, Aunola, \& Nurmi, 2005), while failure is associated with the amount of effort invested by the student (Natale, Aunola, \& Nurmi, 2009; Holloway \& Hess, 1985). The parents of children having borderline intelligence either tend to overestimate the intellectual abilities of their children (Bocsa, 2003), or interpret their school failures as resulting from a lack of motivation or laziness (Masi et al., 1998).

On the basis of our results we conclude that, for students identified as having borderline intelligence, a strong tendency for authoritarian parenting style (i.e., imposing one's will, disregarding the child's opinions, or setting excessively high expectations for the child) is accompanied by a stronger tendency for those students to experience an external locus of control over positive events (e.g., good achievement or learning outcomes). However, parenting style and locus of control did not differ significantly across the groups and the strength of these variables was moderate. Despite this, these patterns are consistent with previous research. Locus of control is an individual characteristic that influences the actions a student will take, their level of motivation for learning, the quality of their academic achievement, and the course of the learning process (Drwal, 1978). Locus of control is shaped in early development and by various experiences. Of particular significance are the educational influences exerted by parents and their attitudes towards parenting (Krasowicz \& KurzypWojnarska, 1990). Rejecting and emotionally cool parenting styles are more likely to lead to an external locus of control (Cohen et al., 2008a; Kurzyp \& Krasowicz, 1989). Children of parents who exhibit an authoritarian parenting style develop low self-concept 
(Lamborn et al., 1991) and lack confidence in their own abilities.

The significant group differences that were observed regarding the relationships between parenting style, locus of control, and motivation for learning may be explained by the greater sensitivity of students having borderline intelligence to experiences associated with the family environment and the parent-child relationship. Previous research has found that children with developmental difficulties are more susceptible to the influences of family factors than their peers (Crnic \& Greenberg, 1987). In this study, students having borderline intelligence more frequently lived in less favourable conditions, were raised in incomplete families, had mothers with a lower education, and had lower family income than their peers. Research by Fenning et al. (2007) demonstrated that mothers of children having below average intelligence were more demanding and critical towards the abilities and behaviours of their children. In addition to lower cognitive abilities, these children exhibit limited coping strategies in response to emotionally difficult situations and have a low level of frustration tolerance (Emerson \& Hatton, 2007; Masi et al., 1998). Problematic relationships among family members result in an increase in emotional difficulties and behavioural disorders for children whose cognitive abilities are below average (Chen, Lawlor, \& Duggan, 2006).

Research indicates that parenting style exerts a significant influence on the course of a child's development. In turn, however, a child's developmental difficulties may shape educational attitudes of parents as well (Floyd \& Phillippe, 1993). Furthermore, the lower a student's motivation for learning as perceived by the teacher, the more likely the teacher will attempt to impose control over the learning process (Dembo, 1997). It is possible that a similar mechanism is active in parents of children having below average intelligence. By taking control of their children's education and learning and establishing a system of rewards and consequences related to academic performance, parents take over educational responsibilities and, ipso facto, change the student's internal motivation to external (Lepper \& Hodell, 1989, quoting: Dembo, 1997). The child is deprived of locus of control and an authentic influence on the process of their own education, and, therefore, their motivation for learning is weakened.

The results of the present study may have significant implications for the process of supporting development and reducing the negative effects of learning

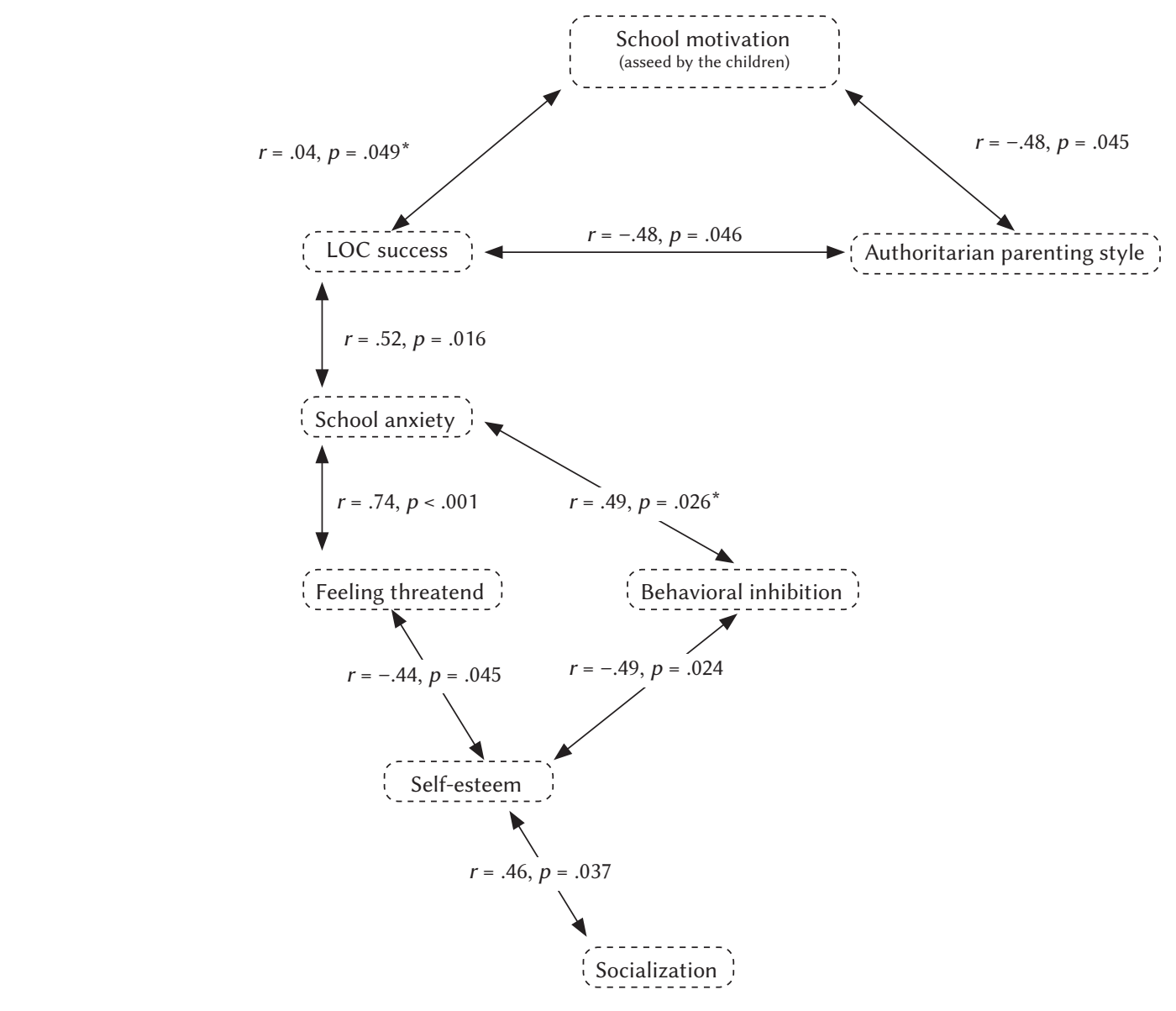

Note. ${ }^{*}$ Correlation is also statistically significant among typically developing children (average intelligence).

Figure 1. Correlation model among borderline intellectual functioning students 
difficulties experienced by students having below average intelligence. That is, the results indicate that it is important to support not just children, but their parents as well. Involving the entire family in the scope of psychological assistance may help children form appropriate attitudes towards academic learning and increase their involvement and sense of responsibility for their educational performance (Fig. 1).

\section{CONCLUSIONS}

Students with BIF did not differ from those with average intelligence on measures of academic motivation, school anxiety, locus of control, self-esteem, or school adaptation. Moreover, both groups were average on these measures. Significant group differences were found, however, in the relationships among particular variables. For students with borderline intelligence, a dominating and rigid parenting style of their mothers was significantly correlated with motivation for learning and locus of control for academic success. These correlations were not observed among students having average cognitive abilities. Since these correlations were apparent only in the borderline intelligence group, it may be that these students are more susceptible the influences exerted by family factors. These factors, in turn, may exert moderating influences on level of school adaptation, involvement in and feeling in control of their academic learning, and academic performance.

This study had a relatively small number of participants in each group. As such, the generalizability of the results is limited and they should not be interpreted to represent all students with BIF.

\section{References}

American Psychiatric Association (2013). Diagnostic and Statistical Manual of Mental Disorder V. Washington: APA.

Ali, R., Akhter, A., Shahzad, S., Sultana, N., \& Ramzan, M. (2011). The impact of motivation of student's academic achievement in mathematics in problem based learning environment. International Journal of Academic Research, 3, 306-309.

Ames, C. (1992). Classrooms: goals, structures, and student motivation. Journal of Educational Psychology, 84, 261-271.

Artigas-Pallarés, J., Rigau-Ratera, E., García-Nonell, C. (2007). Capacidad de inteligencia límite y disfunción ejecutiva [Borderline Intellectual Functioning and executive disfunction]. Revista de Neurología, 44, 67-69.

Baldwin, D., Mclntyre, A., \& Hardaway, E. (2007). Perceived parenting styles on college students' optimism. College Student Journal, 41, 550-557.
Baumrind, D. (1967). Child care practices anteceding three patterns of preschool behavior. Genetic Psychology Monographs, 75, 43-88.

Baumrind, D. (1971). Current patterns of parental authority. Developmental Psychology Monograph, 4, 1-103.

Bimler, D., \& Kirkland, J. (2001). School truants and truancy motivation sorted out with multidimentional saling. Journal of Adolescence Research, 16, 75-102.

Bocsa, E. (2003). School adjustment of borderline intelligence pupils. Summary of doctoral thesis. Psychology and Education Department, University Babeş-Bolyai, Cluj-Napoca.

Boekaerts, M. (1999). Self-regulated learning: where we are today International Journal of Educational Research, 31, 445-457.

Bebko, J. M., \& Luhaorg, H. (1998). The development of strategy use and metacognitive processing in mental retardation: Some sources of difficulty. In: J. A. Burack, \& R. M. Hodapp (eds.), Handbook of mental retardation and development (pp. 382-407). York, NY: Cambridge University Press.

Chen, C. Y., Lawlor, J. P., Duggan, A. K., Hardy, J. B., \& Eaton, W. W. (2006). Mild Cognitive Impairment in Early Life and Mental Health Problems in Adulthood. American Journal of Public Health, 96, 1772-1778.

Chorpita., B. F., \& Barlow, D. H. (1998). The development of anxiety: The role of control in early environment. Psychological Bulletin, 124, 3-21.

Chovan, W. L., \& Morrison E. R. (1984). Correlates of self-concept among variant children. Psychological Reports, 54, 536-538.

Cohen, E., Biran, G., Aran, A., \& Gross-Tsur, V. (2008b). Locus of control, perceived parenting style, and anxiety in children with cerebral palsy. Journal of Developmental and Physical Disabilities, 20, 415-423.

Cohen, D. A., \& Rice, J. (1997). Parenting styles, adolescent substance use, and academic achievement. Journal of Drug Education, 27, 199-211.

Cohen, E., Sade, M., Benarroch, F., Pollak, Y., \& Gross-Tsur, V. (2008a). Locus of control, perceived parentingstyle, and symptoms of anxiety and depression in children with Tourette's syndrome. European Child \& Adolescent Psychiatry, 17, 299-305.

Coolahan, K., McWayne, C., \& Fantuzzo, J. (2002). Validation of multidimensional assessment of parenting styles for low income African-American families with preschool children. Early Childhood Research Quarterly, 17, 356-373.

Cooter, K. S., \& Cooter, R. B. (2004). One size doesn't fit all: Slow learners in the reading classroom. The Reading Teacher, 57, 680-684.

Costigan, C., Floyd, F., Harter, K., \& McClintock, J. (1997). Family process and adaptation to children 
with mental retardation: Disruption and resilience in family problem-solving interactions. Journal of Family Psychology, 11, 515-529.

Crnic, K., \& Greenberg, M. (1987). Maternal stress, social support, and coping: Influences on early mother-child relationship. In: C. Boukydis (ed.), Research on support for parents and infants in the postnatal period (pp. 25-40). NYJ: Ablex.

Deci, E. L., Eghrari, H., Patrick, B. C., \& Leone, D. R. (1994). Facilitating internalization: The self-determination perspective. Journal of Personality, 62, 119-142.

Dekker, M. C., \& Koot, H. M. (2003). DSM-IV disorders in children with borderline to moderate intellectual disability. II: child and family predictors. Journal of the American Academy of Child and Adolescent Psychiatry, 42, 923-931.

Dembo, M. H. (1997). Educational psychology. Warsaw: WSiP.

Dew, T., \& Huebner, E. S. (1994). Adolescents' perceived quality of life: An exploratory investigation. Journal of School Psychology, 32, 185-199.

Dilmaç, B., Hamarta, E., \& Arslan, C. (2009). Analysing the trait anxiety and locus of control of undergraduates in terms of attachment styles. Educational Sciences: Theory \& Practice, 9, 143-159.

Drwal, R. Ł. (1978). Poczucie kontroli jako wymiar osobowości - podstawy teoretyczne, techniki badawcze, wyniki badań [Locus of control as a personality dimension]. In: L. Wołoszynowa (ed.), Materiały do nauczania psychologii. Seria III, t. 3 [Data for teaching psychology]. Warsaw: PWN.

Dusek, J. B. (1980). The development of test anxiety in children. In: I. G. Sarason (ed.), Test anxiety: Theory, research, and applications. Hillsdale, NJ: Lawrence Erlbaum.

Dyduch, E. (1999). Sytuacja dzieci z obniżona sprawnościa intelektualna w szkole podstawowej [Situation of children with low cognitive abilities in primary school]. Rocznik Naukowo-Dydaktyczny w Krakowie, Prace Pedagogiczne XXI.

Emerson, E. (2003). Prevalence of psychiatric disorders in children and adolescents with and without intellectual disabilities. Journal of Intellectual Disability Research, 47, 51-58.

Emerson, E., \& Hatton, C. (2007). Mental health of children and adolescents with intellectual disabilities in Britain. The British Journal of Psychiatry, 191, 493-499.

Fenning, R. M., Baker, J. K., Baker, B. L., \& Crnic, K. A. (2007). Parenting children with Borderline Intellectual Functioning: A unique risk population. American Journal of Mental Retardation, 112, 107-121.

Floyd, F. J., Harter, K., \& Costigan, C. (2004). Family problem-solving with children who have mental retardation. American Journal on Mental Retardation, 109, 507-524.
Floyd, F. J., \& Phillippe, K. A. (1993). Parental interactions with children with and without mental retardation: Behavior management, coerciveness, and positive exchanges. American Journal on Mental Retardation, 97, 673-684.

Forehand, R., \& Nousiainen, S. (1993). Maternal and paternal parenting: Critical dimensions in adolescent functioning. Journal of Family Psychology, 7, 213-221.

Gadeyne, E., Ghesquiere, P., \& Onghena, P. (2004). Psychosocial functioning of young children with learning problems. Journal of Child Psychology and Psychiatry, 45, 510-521.

Gfroerer, K., Kern, R., \& Curlette, W. (2004). Research support for individual psychology's parenting model. Journal of Individual Psychology, 61, 379-388.

Gindrych, P. (2002). Psychosocial functioning of children with developmental dyslexia. Lublin: UMCS.

Gonzalez, A. L., \& Wolters, C. A. (2006). The relationship between perceived parenting practices and achievement motivation in mathematics. Journal of Research in Childhood Education, 21, 203-217.

Gottfried, A. E. (1982). Relationship between academic instrinsic motivation and anxiety in children and young adolescence. Journal of School Psychology, 20, 205-215.

Gottlieb, J., Alter, M., Gottlieb, B. W., \& Wishner, J. (1994). Special education in urban America: It's not justifiable for many. Journal of Special Education, 27, 453-465.

Grouzet, F. M. E., Vallerand, R. J., Thill, E. E., \& Provencher, P. J. (2004). From environmental factors to outcomes: A test of an integrated motivational sequence. Motivation and Emotion, 28, 331-346.

Hassiotis, A., Strydom, A., Hall, I., Ali, A., Lawrence-Smith, G., Meltzer, H., Head, J., \& Bebbington, P. (2008). Psychiatric morbidity and social functioning among adults with borderline intelligence living in private households. Journal of Intellectual Disability Research, 52, 95-106.

Hayes, S., Shackell, P., Mottram, P., \& Lancaster, R. (2007). The prevalence of intellectual disability in a major UK prison. British Journal of Learning Disabilities, 35, 162-167.

Holloway, S. D., \& Hess, R. D. (1985). Mothers' and teachers' attributions about children's math performance. In: I. E. Sigel (ed.), Parental belief systems: The Psychological consequences for children. Hillsdale, NJ: Lawrence Erlbaum Press.

Jacobsen, B., Lowery, B., \& Du-Cette, J. (1986). Attributions of learning disabled children. Journal of Educational Psychology, 78, 59-65.

Jankowska, A., Bogdanowicz, M., \& Takagi, A. (2014). Stability of WISC-R scores in students with borderline intellectual functioning. Health Psychology Report, 2, 49-59.

Jones, D. C., Rickel, A. U., \& Smith, R. L. (1980). Maternal child-rearing practices and social problem 
solving strategies among preschoolers. Developmental Psychology, 16, 241-242.

Kaisa, A., Hakan, S., \& Jari-erik, N. (2000). Parenting styles and adolescents' achievement strategies. Journal of Adolescence, 23, 205-222.

Kalechstein, A. D., \& Nowicki, S., Jr. (1997). A meta-analytic examination of the relationship between control expectancies and academic achievement: An 11-year follow-up to Findley and Cooper. Genetic, Social, and General Psychology Monographs, 123, 27-56.

Karende, S., Kanchan, S., \& Kulkarni, M. (2008). Clinical and psychoeducational profile of children with borderline intellectual functioning. Indian Journal of Pediatrics, 75, 795-800.

Kauffman, D., Gaston, E., Santa Lucia, R., Salcedo, O., Rendina-Gobioff, G., \& Gadd, R. (2000). The relationship between parenting style and children's adjustment: The parents' perspective. Journal of Child and Family Studies, 9, 231-245.

Kaznowski, K. (2004). Slow learners: Are educators leaving them behind? National Association of Secondary School Principals, 88, 31-45.

Kee, T. T. (2005). A cultural interpretation of locus of control, family and school experience, and school truancy - The case of Hong Kong. International Journal Adolesce and Youth, 124, 325-349.

Kinlaw, C. R., Kurtz-Costes, B., \& Goldman-Fraser, J. (2001). Mothers' achievement beliefs and behaviors and their children's school readiness: A cultural comparison. Journal of Applied Developmental Psychology, 22, 493-506.

Kistner, J. A., Osborne, M., \& LaVerrier, L. (1988). Causal attributions of learning disabled children: Developmental patterns and their relation to academic progress. Journal of Educational Psychology, 80, 82-83.

Krasowicz, G., \& Kurzyp-Wojnarska, A. (1987). Społeczne wyznaczniki poczucia kontroli następstw zdarzeń [Social determinants of locus of control over outcomes]. Educational Psychology, 30, 524-532.

Krasowicz, G., \& Kurzyp-Wojnarska, A. (1990). Kwestionariusz do Badania Poczucia Kontroli KBPK [The Locus of Control Research Inventory]. Warsaw: PTP.

Kurzyp, A., \& Krasowicz, G. (1989). Kwestionariusz Do Pomiaru Poczucia Kontroli u Młodzieży Dorastającej [Questionnair of Locus of Control in Adolescence]. In: R. Ł. Drwal (ed.), Techniki kwestionariuszowe $w$ diagnostyce psychologicznej $[\mathrm{Qu}-$ estionnaires in psychological assessment]. Lublin: University of Marii Curie-Skłodowska.

Lamborn, S. D., Mounts, N. S., Steinberg, L., \& Dornbusch, S. M. (1991). Patterns of competences and adjustment among adolescence from authoritative, authoritarian, indulgent, and neglectful families. Child Development, 62, 1049-1065.
Levine, M. (2003). Celebrating diverse minds. Educational Leadership, 61, 14-18.

Maccoby, E. E., \& Martin, J. A. (1983). Socialization in the context of the family: Parent-child interaction. In: P. H. Mussen (ed.), E. M. Hetherington (vol. ed.), Handbook of child psychology: Vol. 4. Socialization, personality, and social development. New York: Wiley.

Markowska, B., \& Szafraniec, H. (1980). Podręcznik do "Arkusza Zachowania się Ucznia” B. Markowskiej [Children's Behaviour Inventory Manual]. In: M. Choynowski (ed.), Testy psychologiczne w poradnictwie wychowawczo-zawodowym [Psychological tests in educational and vocational guidance]. Warsaw: PWN.

Marsh, H.W., \& Yeung, A. S. (1997). The causal effects of academic self-concept on academic achievement: Structural equation models of longitudinal data. Journal of Educational Psychology, 89, 41-54.

Masi, G., Marcheschi, M., \& Pfanner, P. (1998). Adolescents with borderline intellectual functioning: Psychopathological risk. Adolescence, 33, 425-434.

McCollum, J. A., Gooler, F. G., Appl, D. J., \& Yates, T. J. (2001). PIWI: enhancing parent-child interaction as a foundation for an early intervention. Infant \& Young Children, 14, 34-45.

McLeod, B. D., Wood, J. J., \& Weisz, J. R. (2007). Examining the association between parenting and childhood anxiety: A meta-analysis. Clinical Psychology Review, 27, 155-172.

MacMillan, D. L., Gresham, F. M., Bocian, K. M., \& Lambros, K. (1998). Current plight of borderline students: Where do they belong? Education \& Training in Mental Retardation \& Developmental Disabilities, 33, 83-94.

Meesters, C., \& Muris, P. (2004). Perceived parental rearing behavior and coping in young adolescents. Personality and Individual Differences, 37, 513-522.

Mega, C., Ronconi, L., \& De Beni, R. (2013). What makes a good student? How emotions, self-regulated learning, and motivation contribute to academic achievement. Journal of Educational Psychology, 106, 121-131.

Milevsky, A., Schlechter, M., Netter, S., \& Keehn, D. (2006). Maternal and paternal parenting styles in adolescents: Associations with self-esteem, depression, and life satisfaction. Journal of Child and Family Studies, 16, 39-47.

Natale, K., Aunola, K., \& Nurmi, J.-E. (2009). Children's school performance and their parents' causal attributions to ability and effort: A longitudinal study. Journal of Applied Developmental Psychology, 30, 14-22.

Nesselroade, J. R., Musher-Eizenman, D. R., \& Schmitz, B. (2002). Perceived control and academic performance: a comparison of high and low performing children on within person change patterns. International Journal of Behavioral Development, 26, 540-547. 
Ninivaggi, F. (2005). Borderline intellectual functioning and academic problem. In: B. J. Sadock, \& V. A. Sadock (eds.), Kaplan \& Sadock's comprehensive textbook of psychiatry ( $8^{\text {th }}$ ed.). Baltimore: Lippincott Williams and Wilkins.

Ninivaggi, F. J. (2008). Borderline intellectual functioning in children and adolescents. Devereux Glenholme School. http://www.theglenholmeschool. org/special\%20topics/borderline.htm.

Nunn, G. D., \& Parish, T. S. (1992). The psychosocial characteristics of at-risk high school students. Adolescence, 27, 435-441.

Obuchowska, I. (1981). Dynamika nerwic: psychologiczne aspekty zaburzeń nerwicowych u dzieci i mlodzieży [The dynamics of neurosis: the psychological aspects of neurotic disorders in children and adolescents]. Warszawa: Państwowe Wydawnictwo Naukowe.

Ostrander, R., \& Herman, K. C. (2006). Potential cognitive, parenting and developmental mediators of the relationship between ADHD and depression. Journal of Consulting and Clinical Psychology, 74, 89-98.

Patock-Peckham, J. A., \& Morgan-Lopez, A. A. (2006). College drinking behaviors: mediational links between parenting styles, impulse control, and alcohol-related outcomes. Psychology of Addictive Behaviors, 20, 117-125.

Phillips, B. N., Pitcher, G. D., Worsham, M. E., \& Miller, S. C. (1980). Test anxiety and the school environment. In: I. G. Sarason (ed.), Test anxiety: Theory, research, and applications. Hillsdale, NJ: Lawrence Erlbaum.

Pintrich, P. R., Anderman, E. M., \& Klobucar, C. (1994). Intraindividual differences in motivation and cognition in students with and without learning disabilities. Jorunal of Learning Disabilities, 27, 360-370.

Pong, S., Johnston, J., \& Chen, V. (2010). Authoritarian parenting and Asian adolescent school performance: Insights from the US and Taiwan. International Journal of Behavioral Development, 34, 62-72.

Reitman, D., Rhode, P., Hupp, S. D. A., \& Altobello, C. (2002). Development and validation of the Parental Authority Questionnaire-Revised. Journal of Psychopathology and Behavioral Assessment, 24, 119-127.

Rosenberg, M. (1965). Society and the adolescent self-image. Princeton, NJ: Princeton University Press.

Russell, S. T., Crockett, L. J, \& Chao, R. K. (2010). Conclusions: The role of Asian America culture in parenting and parent-Adolescent relationships. In: S. T. Russell, L. J. Crockett, \& K. Chao (eds.), Advancing responsible adolescent development: Asian American parenting and parent-adolescent relationships (pp. 117-128). Springer: New York.

Rytkönen, K., Aunola, K., \& Nurmi, J. E. (2005). Parents' causal attributions concerning their chil- dren's school achievement: A longitudinal study. Merrill-Palmer Quarterly, 51, 494-522.

Salvador-Carulla, L., García-Gutiérrez. J. C., Gutiérrez-Colosía, M. R., Artigas-Pallarès, J., García Ibáñez, J., González-Pérez, J., Nadal Pla, M., Aguilera Inés, F., Isus, S., Cereza, J. M., Poole, M., Portero Lazcano, G., Monzón, P., Leiva, M., Parellada, M., García Nonell, K., Martínez-Hernández, A., Rigau, E., \& Martínez-Leal, R. (2013). Borderline Intellectual Functioning: Consensus and good practice guidelines. Revista de Psiquiatria y Salud Mental, 6, 109-120.

Sangeeta, S. S., \& Krishna, D. (2009). Impact of intervention package on mental abilities of 5-6 years old slow learners. Journal of Dairying Foods \& Home Sciences, 28, 209-214.

Shaw, S. R. (2008). An educational programming framework for a subset of students with diverse learning needs: borderline intellectual functioning. Intervention in School and Clinic, 43, 291-299.

Shumow, L., Vandell, D. L., \& Posner, J. K. (1998). Harsh, firm, and permissive parenting in low-income families. Journal of Family Issues, 19, 483-507.

Smith, C. L., Calkins, S. D., Keane, S. P., Anastopoulos, A. D., \& Shelton, T. L. (2004). Predicting stability and change in toddler behavior problems: contributions of maternal behavior and child gender. Developmental Psychology, 40, 29-42.

Smith, D. E., \& Moore, T. M. (2012). Parenting style and psychosocial outcomes in a sample of Jamaican adolescents. International Journal of Adolescence and Youth, 1, 1-15.

Spionek, H. (1973). Zaburzenia rozwoju uczniów a niepowodzenia szkolne [Students' developmental disorders and school failure]. Warsaw: PWN.

Stevenson, H. W., Chen, C., \& Uttal, D. H. (1990). Beliefs and achievement: A study of Black, White, and Hispanic children. Child Development, 61, 508-523.

Strage, A., \& Brandt, T. S. (1999). Authoritative parenting and college students' academic adjustment and success. Journal of Educational Psychology, 91, 146-456.

Suchman, N. E., Roundsaville, B., DeCoste, C., \& Luthar, S. (2007). Parental control, parental warmth, and psychological adjustment in a sample of substance-abusing mothers and their school-aged and adolescent children. Journal of Substance Abuse Treatment, 32, 1-10.

Swanson, J., Valiente, C., \& Lemery-Chalfant, K. (2012). Predicting academic achievement from cumulative home risk: The mediating roles of effortful control, academic relationships, and school avoidance. Merrill-Palmer Quarterly, 58, 375-408.

Tyszkowa, M. (1990). Zdolności, osobowość i dziatalność uczniów [Students' abilities, personality and accomplishments]. Warsaw: PWN. 
Valliant, G. E., \& Davis, J. T. (2000). Social/emotional intelligence and midlife resilience in schoolboys with low tested intelligence. American Journal of Orthopsychiatry, 70, 215-222.

Vansteenkiste, M., Simons, J., Lens, W., Sheldon, K. M., \& Deci, E. L. (2004). Motivating learning, performance, and persistence: The synergic role of intrinsic goals and autonomy-support. Journal of Personality and Social Psychology, 87, 246-260.

Wentzel, K. R. (1998). Social relationships and motivation in middle school: the role of parents, teachers, and peers. Journal of Educational Psychology, 90, 202-209.

Wenglinski, H. (2000). How teaching matters: Bringing the classroom back into discussions of teacher quality. Princeton, New York: Educational Testing Service.

Wigfield, A., \& Cambria, J. (2010). Students' achievement values, goal orientations, and interest: definitions, development, and relations to achievement outcomes. Developmental Review, 30, 1-35.

World Health Organization (1994). International Classification of Diseases (ICD-10). WHO: Geneva.

Wyczesany, J. (2004). Pedagogika upośledzonych umystowo [Pedagogy of the intellectually disabled individuals]. Kraków: Impuls.

Ziemska, M. (1981). Kwestionariusz dla Rodziców do Badania Postaw Rodzicielskich [Parenting Style Inventory]. Warsaw: PWN.

Ziemska, M. (1977). Rodzina a osobowość [Family and personality]. Warsaw: Wiedza Powszechna.

Zwierzyńska, E., \& Matuszewski, A. (2006). Kwestionariusze „Klasa wobec mnie”, „Ja wobec klasy" [Questionnaire „My Classroom and I"]. Warsaw: CMPPP.

Zwierzyńska, E., \& Matuszewski, A. (2006). Skala jawnego niepokoju „Jaki jesteś?” E. Skrzypek i M. Choynowskiego [Skrzypek \& Choynowski's scale of explicit anxiety “What are you like?"]. Warsaw: CMPPP. 